\title{
DIMENSIONS OF LIQUIDITY AND THEIR FACTORS IN THE SLOVENIAN BANKING SECTOR
}

\author{
Jana Laštůvková
}

\section{Introduction}

The interest in bank liquidity has grown significantly in recent times not only among regulators, but in authors' studies as well. The trigger mechanism was mainly the recent global financial crisis, where a number of systems faced liquidity problems. On the basis of the crisis, the regulation on the part of the Basel Committee (Bank for International Settlements, 2010 ) in the area of liquidity has increased. The Basel Committee proposed the introduction of two liquidity indicators: the LCR (Liquidity Coverage Ratio) and the NSFR (Net Stable Funding Ratio), which the member states must obligatorily fulfil based on European law. The LCR indicator has already come in force in January 2015. The purpose of these two indicators is to increase the resistance and stability of banking systems in case of further crises, and to increase the ability to overcome crisis periods on the basis of pre-created "reserves" and stable forms of financing in both short-term and long-term.

During the crisis, a number of systems have shown a decrease in the creation of liquidity, caused mainly by a decrease in market liquidity on financial markets, where liquidity had often been procured by the banks before. Apart from the decreased creation of liquidity, the banks (systems) also faced a higher liquidity outflow caused by the economic downturn. The banks had to cover the emerging liquidity shortages from both client and private trades. These two effects are often mentioned by authors dealing with the influences of the recent global crisis on bank liquidity (see Geršl \& Komárková, 2009; Moore, 2010; Eroglu \& Eroglu, 2011).

In addition to the introduction of the liquidity indicators in Basel III, the interest of authors in bank liquidity has increased as well. Their studies are generally focused on the above mentioned relation between liquidity and the crisis, or the relation between liquidity and financial stability as a whole. The term "financial stability" has become a key word not only in a number of regulatory measures, but also in studies focusing on the options of increasing and ensuring it. The majority of studies supported the idea that an increased bank liquidity will increase financial stability, as can be seen, for example, in Crockett (2008) or Nguyen, Skully, and Perera (2013); there were, however, also opinions that too large an amount of liquidity in banks disrupts stability, since a larger amount of risk is being assumed (Wagner, 2007). The authors also dedicated and continue to dedicate a large amount of attention to seeking key determinants which influence bank liquidity. The majority of studies, however, only focus on the effect of these factors on the creation of liquidity - the first effect of the crisis - but overlook the second effect, i.e. the outflow of liquidity, which has also surfaced during the crisis. Therefore, it is the goal of this article to also include outflow and other dimensions of liquidity into the regression models.

The aim is to identify the internal factors which influence the chosen bank sector using the multidimensional linear regression analyses. The regressions operate with a larger number of dependent variables to represent different views on the liquidity risk. These dependent variables are calculated according to a specific method of measuring liquidity risk - the method used by the authors Valla, Saes-Escorbiac, and Tiesset (2006). These variables include the positive flow, representing the creation of liquidity, the negative flow, representing the outflow of liquidity, net change, and total reallocation, i.e. the activity in the system. The chosen sector is the Slovenian banking sector in the period of 2001-2013. 


\section{Literature Review}

\subsection{Liquidity Measurement Used}

Studies investigating the determinants of liquidity almost always work with two main concepts of measuring liquidity risk on the side of the dependent variable. They either use financial ratios or the method of liquidity creation based on Berger and Bouwman (2009). In some cases, the method of liquidity creation is complemented by LT gap based on the work of Deep and Schaefer (2004).

When using financial ratios, authors often work with a larger number of them. They utilize variables such as loans, deposits and their modifications, and relate them to total or liquid assets. Aside from the typical indicator of liquidity, i.e. liquid assets/total assets (see Bunda \& Desquilbet, 2008; Vodová, 2011a; 2011b; 2012; 2013; Trenca, Petria, Mutu, \& Corovei, 2012) another indicator is widely used - liquid assets/deposits and its modifications (total deposits, client deposits, short-term deposits, etc.) see for example: (Bunda \& Desquilbet, 2008; Vodová, 2011a; 2011b; 2012; 2013; Bonfim \& Kim, 2013). Cucinelli (2013) chooses a different take on financial ratios. In his regression models, he works with liquidity indicators included in the Basel III concept: LCR (high quality liquid assets/total net outflow over the next 30 calendar days) and NSFR (the available amount of stable funding/required amount of stable funding).

The second concept of liquidity risk measurement which appears on the side of the dependent variable is liquidity from the aspect of its creation based on specific measurement method created by Berger and Bouwman (2009). Berger and Bouwman (2009) talk about the creation of liquidity, or a dynamic method of measuring liquidity which for some authors is a better expression of liquidity risk than financial ratios, which represent static measurements of liquidity risk. Authors working with the Berger and Bouwman (2009) method are for instance Horvath, Seidler, and Weill (2012) and Pana, Park, and Query (2010). The Berger and Bouwman (2009) method is based on dividing all the balance and off-balance items by liquidity into three groups - liquid, semi-liquid and illiquid. This division is performed based on two perspectives - the category of the given item (cat measurement) and its maturity (mat measurement). Subsequently, these three groups are assigned weights and four possible measurements of liquidity creation are obtained - combinations according to category/maturity and with/without off-balance items.

As said in the introduction, some authors complement the measurement of liquidity creation based on Berger and Bouwman (2009) by measurement based on Deep and Shaefer (2004) - the so called LT gap (see Lakštutiene and Krušinskas (2010) who explore the Lithuanian banking sector; Hackethal, Rauch, Steffen, and Tyrell (2010) who deal with German savings banks). LT gap (liquidity transformation gap) is calculated as the difference of the liquid liabilities and liquid assets weighted by total asset value. Deep and Schaefer (2004) divide assets into liquid and illiquid and liabilities into deposits (and other short-term liabilities with a maturity of one year), long-term deposits and equity. Of these three components, only deposits are liquid. The aim of the measurement is to determine how the value of liquid assets differs from the value of liquid liabilities - to discover the net "excess". The value of the calculated gap can range between -1 and 1 . In the event that the bank has the same value of liquid assets and liabilities, its LT gap is zero.

Whether the authors work with financial ratios or the liquidity creation method and LT gap, they either choose the influence of a specific chosen factor (Bunda and Desquilbet (2008) deal with the influence of the exchange rate regime of liquidity; Berger and Bouwman (2009) and Horvath et al. (2012) focus on the influence of capital on the creation of liquidity; Pana, Park, and Query (2010) study the influence of mergers on the liquidity creation value), or choose the general potential determinants on both the micro- and the macroeconomic level (see Vodová, 2011a; 2011b; 2012; 2013; Trenca et al., 2012; Hackethal et al., 2010; Lakštutiene \& Krušinskas, 2010 etc.).

Regression models are applied by the authors to only one sector (Hackethal et al., 2010; Horvath et al., 2012), to selected units (Pana et al., 2010; Bonfim \& Kim, 2012; Trenca et al., 2012), or to multiple sectors at once (Bunda \& Desquilbet, 2008; Cucinelli, 2013) especially in order to obtain higher information value from macroeconomic variables.

It can be summarized that in the regression analyses performed by the above authors, the side of the dependent variable works either with a static view (financial ratios) or a dynamic view from the position of liquidity creation or net 
change (LT gap). However, hardly any studies utilize liquidity outflow as a dependent variable; Laštůvková (2015) is the only noteworthy study in this respect, as it points to the influence of the most common general factors in the Slovak sector on liquidity outflow (measured based on the method created by Valla et al. (2006)) and stresses that relationships thus do not necessarily only exist between liquidity creation and certain factors, but apply to liquidity outflow as well. Moreover, when evaluating the influence of one factor on the creation of liquidity, a false belief may be created that the end result of this factor's effect is the creation of liquidity. This same factor can influence the outflow of liquidity in a greater extent, and can thus lead to liquidity outflow from the system. This phenomenon is then showcased by Laštůvková (2015) in the regression analyses performed. An important fact stressed already by Valla et al. (2006) is the simultaneous effect of both flows (positive and negative): liquidity is both created and lost in a given time period. Even though a given factor is affecting a given flow, the effect on the second flow may be much more prominent and may affect the net change value.

In this respect, the studies dealing with the influence of the crisis on liquidity must again be mentioned (see Geršl \& Komárková, 2009; Moore, 2010; Eroglu \& Eroglu, 2011). The authors coincidently state that due to the crisis, liquidity creation decreases while its outflow increases.

Due to the above mentioned reasons and the absence of outflow of liquidity as a potential dependent variable, this study uses the method created by Valla et al. (2006) and constructs the liquidity flows (including liquidity outflow) which are then used as dependent variables in the regression analyses performed. The method created by Valla et al. (2006) is based on the value of liquid assets during a given period which have been converted to the shape of individual flows: positive, negative and net flow. The authors further constructed the total reallocation value, since net changes do not always reflect the total creation and outflow in the given time period. Using this method, the authors evaluated the flows in the French banking system between 1993 and 2005; however, they did so without constructing regression models or seeking potential determinants. According to the present author, this method provides a comprehensive look at liquidity measurement which allows multiple points of view. Its benefit is mainly the ability to measure the negative flow, i.e. liquidity outflow and total reallocation, which have not figured as dependent variables in other studies.

\subsection{Applied Microeconomic Factors}

The present article focuses only on the effect of microeconomic factors, i.e. factors specific to the individual banks. The majority of studies dealing with factors affecting liquidity include microeconomic factors along with macroeconomic ones. This is justifiable, since liquidity is affected by both internal and external determinants. However, it is the aim of the author to determine the extent to which internal factors contribute to the liquidity value. Moreover, the article works with only one sector, where the potential influence of external factors might not manifest as extensively. The internal factors usually include: total balance sum representing the size of banks (see Vodová, 2011a; 2011b; 2012; 2013; Bonfim \& Kim, 2013; Bunda \& Desquilbet, 2008; Cucinelli, 2013), which authors often associate with a concept known as "too big to fail" and evaluate the relationship as negative; profit value (before or after tax) (see Hackethal et al., 2010; Bonfim \& Kim, 2013) with negative influence; the value of equity (authors often study this factor separately, see Berger \& Bouwman, 2009; Fungáčová, Weill, \& Zhou, 2010; Distinguin, Roulet, \& Tarazi, 2013 etc.), where authors lean more towards a negative relationship while also noting that the type and the size of banks plays a vital role; size of loans (see Vodová, 2011a; 2011b; 2012; 2013; Hackethal et al., 2010; Bonfim \& Kim, 2013; Cucinelli, 2013; Lakštutiene \& Krušinskas, 2010) with negative influence; or the value of deposits (Lakštutiene \& Krušinskas, 2010) with positive influence. The factors used are expressed differently by various authors, as for example equity as the value of total equity, value of only Tier 1 capital, or equity expressed as a ratio to the total value of assets; similar differences occur in other factors as well.

\section{Methodology}

To determine the internal factors influencing the chosen liquidity flows, robust regression analyses are performed. The general equation of the model is as follows: 
Liquidity $(P O S / N E G / N E T / T O T)=$

$=\alpha+\beta 1$ Loans $+\beta 2$ Deposits +

$+\beta 3$ Profit $+\beta 4$ Equity $+\beta 5$ Size +

$+\beta 6$ Ratio $+\varepsilon$

On the side of the variable being explained appear the individual calculated liquidity flows. These are the positive flow (POS) representing the creation of liquidity, the negative flow (NEG) representing the outflow of liquidity, the net change (NET) as the difference between the above mentioned flows, and the total reallocation (TOT), which represents the activity in the system. The studied sample is the banking sector of the Republic of Slovenia, excluding the branches of foreign banks. The development is evaluated between the years 2001 and 2013. The individual flows and reallocations were calculated on the basis of the method created by Valla et al. (2006). To obtain these flows, the following method of processing the value of liquid assets is used:

- Determining the year-on-year changes in liquid assets

$$
\Delta I_{i t}=I_{i t}-I_{i t-1}
$$

where $I_{i t}$ is the liquidity value of bank $i$ in time $t$, $l_{i t-1}$ is the liquidity value of bank $i$ in time $t-1$.

- Determining the adjusted growth rate

Relation (3) is used to determine the adjusted growth rate of liquidity in time $t$ for each bank:

$$
g_{i t}=\frac{\Delta I_{i t}}{\left(I_{i t-1}+I_{i t}\right) / 2}
$$

- Determining the liquidity flows

By aggregating the values obtained from relation (4), either positive (5) (where $g_{i t} \geq 0$ ) or negative (4) (where $g_{i t} \leq 0$ ) nominal flows are obtained.

$$
\begin{aligned}
& \operatorname{POS}_{t}^{\text {nom }}=\sum_{i \mid g_{i t} \geq 0}^{N} g_{i t}\left(\frac{\left(I_{i t-1}+l_{i t}\right) / 2}{\sum_{i=1}^{N} I_{i t-1}}\right) \\
& N E G^{n o m}{ }_{t}=\sum_{i \mid g_{i t} \leq 0^{0}}^{N}\left|g_{i t}\right|\left(\frac{\left(l_{i t-1}+l_{i t}\right) / 2}{\sum_{i=1}^{N} I_{i t-1}}\right)
\end{aligned}
$$

For positive flows, only positive (or zero) values of adjusted growth rate of individual banks are considered, weighted by the average share of total liquidity; for negative flows, only negative (zero) values of $g_{i t}$ are considered.

- Calculation of the net changes

Whether a drop or a growth in liquidity of the given system occurred is determined via net liquidity flows.

$$
N E T_{t}^{n o m}=\operatorname{POS}_{t}^{\text {nom }}-N E G_{t}^{\text {nom }}
$$

- Determining the total reallocation

Determining the total activity in the sector in the given time period.

$$
\begin{aligned}
& \text { TOT }_{t}^{\text {nom }}{ }_{t}=\operatorname{POS}_{t}+N E G^{\text {nom }}{ }_{t}- \\
& -\left|N E T^{\text {nom }}{ }_{t}\right|
\end{aligned}
$$

The value of liquid assets in the time period was obtained from the Bankscope database on an annual basis. The database defines liquid assets as follows:

Liquid assets

= Trading securities at FV through income

+ Loans and advances to banks

+ Reverse repos and cash collateral

+ Cash and due from banks

- Mandatory minimum reserves.

On the side of the independent variables stand the internal factors with potential influence on bank liquidity. These variables include:

- loans, i.e. net loans (N_LOAN), gross loans (G_LOAN) and allowance for loans losses (AĹL),

- deposits, i.e. client deposits (C_DEP) and total deposits (deposits and short term funding) (T_DEP),

- the value of profit, i.e. profit before taxation (B_TAX) and profit after taxation (A_TAX),

- the value of equity (EQU),

- the value of total assets, representing the size of the bank (TA),

- gross loans/client deposits financial ratio (RATIO).

The predicted mathematical signs expressing the positive/negative relation must be discussed independently for individual flows. The above mentioned studies work mainly with liquidity creation. The relations obtained thus correspond with the relation between liquidity creation and the variables: in this 
case, the positive flow and the given factors. In the case of liquidity outflow, representing the negative flow, simplified consideration of the problem would allow us to assume an opposite relation. However, it must be noted that any given factor can influence one of the flows without influencing the other, or influence one of the flows in a more significant way. For instance, when the value of deposits drops from 100 to 80 , there are a number of potential scenarios to consider. The drop could by caused by a withdrawal of deposits on the side of the clients, and thus liquidity outflow, which would generate a negative relation between deposit value and outflow, without the positive flow playing a role. It is highly probable, however, as Valla et al. (2006) state that both flows operate simultaneously, with one flow being more dominant than the other - in this case, the liquidity outflow. For the reasons of simultaneous influence of both flows, a reverse relation between the creation/outflow of liquidity and the given factors is considered.

In the case of net changes (NET), it is impossible to determine the predicted sign in advance, since this depends on one flow being dominant. In the case of signs identical to those in the NEG value, it is assumed that the positive flow is dominant at the given time, while in the case of the opposite sign, the outflow of liquidity at the given time is expected to be dominant. In other words, in case of simultaneous influence of both flows, higher NET is caused by higher creation of liquidity and lower outflow, lower NET conversely by higher outflow and lower creation.

Specifically, a negative relation for the value of equity and liquidity creation is assumed, stemming from the theory of crowding out deposits conceived by Gorton and Winton (2001) where the higher value of capital, as a component of liabilities, leads to reductions in another liability component, deposits, while the bank capital is not endangered by runs on the bank and the banks are not forced to "cover" it by the liquidity value, as they would in the case of deposit growth. Recently, thanks to increased regulatory activity, there is a clear increase in the value of capital, and thus, based on this theory, deposits are being crowded out and liquidity creation decreased.

In the case of bank size, determined mainly by the value of total assets, studies work with the theory of "too big to fail", where large banks hold smaller amounts of liquidity and the relationship between the variables is reverse. Large banks rely on being able to quickly obtain liquidity from markets, since holding it is not profitable. At a pinch, they can turn to the central bank or the state for help. The smaller a bank is (the lower the value of its total assets is), the more difficult access it has to the financial markets, and the more it has to rely on itself, which means it holds liquidity more than larger banks. For groups of smaller banks specifically, we could even speak of a positive relation. A different approach to managing the liquidity value based on bank size is worked with for example by Laštůvková (2014), who specifies a negative relationship for banks of the large category in the Czech sector, and a positive relationship for banks of the small category - that is, the small banks cover the growth in their assets by an appropriate increase in liquid assets. The Slovenian sector in question is smaller than the Czech one, meaning that we can assume a positive relation for the sector as a whole. In addition, large Slovenian banks do not hold a majority market share; the developments in the flows of the entire sector will not be determined solely by the large banks, but by a weighted average of the development in other groups, especially the group of banks in the middle category. This can also affect the final positive relation between the value of total and liquid assets (their creation). In this case, it is very difficult to determine the relation for liquidity outflow, since it can either increase or decrease with growing value of total assets. In case of a positive relation and an assumption of creation and holding of liquidity on the side of small banks, we can also assume a lower outflow, in order to prevent liquidity from "draining away". On the other hand, the small banks which rely on themselves may also be forced to use up liquidity extensively, which would subsequently mean the need to increase the creation ratio in order to maintain a neutral position.

In the case of profit, the prerequisite is an investment triangle, where liquidity is the counterbalance to profitability; in the general scope, a negative relation would be assumed between the value of liquidity creation and profit.

In the case of loan value, the study works with a negative relation as determined by a number of studies (see above) where a higher tendency to provide loans leads to lower 
creation and higher outflow and vice versa. For deposits, similarly to other studies, a positive relation to liquidity creation is assumed.

For allowance for loans losses, a positive relation can be assumed, where banks create liquid reserves based on higher risk in the portfolio. These reserves can then be used to cover any potential future fluctuations caused by clients.

The loans/deposits ratio used in the calculation is assumed to have a negative relation. If an increase in the ratio is caused by an increase in lending or a decrease in deposits, a liquidity outflow will occur and a decrease in creation will follow.

All the variables used were obtained from the Bankscope database and represent relative annual changes. The calculations were performed in Stata software, with a significance level of $95 \%$.

\section{Results}

Due to the significant correlations found between the net and gross loans, between client deposits and total deposits, and between profit before and after taxation, these variables were always inserted into the models separately. The following table (Tab. 1) presents the best model for liquidity creation (POS). A significant amount of the chosen variables have proven to be significant, the determination coefficient is also very high, and it seems creation of liquidity is affected by internal factors the most. The best models with the highest determination coefficient and the lowest information criteria were the models including net loans alongside net profit, as seen in Tab. 1 (1) and (2). Models including profit before taxation were also significant, as were those including gross loans. Here however, the value of allowance for loans losses also figured in the model, while the RATIO ceased being significant. When the total deposits item was included, the models were not significant.

\section{Tab. 1: Results for creation of liquidity (POS)}

\begin{tabular}{|c|c|c|c|c|}
\hline POS (creation) & (1) & (2) & (3) & (4) \\
\hline EQU & $\begin{array}{l}0.895^{\star *} \\
(0.002)\end{array}$ & $\begin{array}{l}0.812^{\star *} \\
(0.001)\end{array}$ & $\begin{array}{l}0.855^{\star *} \\
(0.009)\end{array}$ & $\begin{array}{l}0.779^{*} \\
(0.014)\end{array}$ \\
\hline A_TAX & $\begin{array}{c}-0.0140^{*} \\
(0.025)\end{array}$ & & $\begin{array}{c}-0.0125^{*} \\
(0.029)\end{array}$ & \\
\hline B_TAX & & $\begin{array}{c}-0.0144^{*} \\
(0.012)\end{array}$ & & $\begin{array}{c}-0.0129^{*} \\
(0.013)\end{array}$ \\
\hline N_LOAN & $\begin{array}{c}-0.633^{* *} \\
(0.009)\end{array}$ & $\begin{array}{c}-0.613^{\star *} \\
(0.008)\end{array}$ & & \\
\hline G_LOAN & & & $\begin{array}{l}-0.599^{*} \\
(0.014)\end{array}$ & $\begin{array}{l}-0.528^{*} \\
(0.011)\end{array}$ \\
\hline ALL & & & $\begin{array}{l}0.168^{* *} \\
(0.003)\end{array}$ & $\begin{array}{l}0.165^{\star *} \\
(0.003)\end{array}$ \\
\hline C_DEP & $\begin{array}{l}0.996^{\star *} \\
(0.001)\end{array}$ & $\begin{array}{c}1.021^{* * *} \\
(0.001)\end{array}$ & $\begin{array}{l}0.807^{\star *} \\
(0.008)\end{array}$ & $\begin{array}{l}0.834^{* *} \\
(0.008)\end{array}$ \\
\hline RATIO & $\begin{array}{c}0.0932^{*} \\
(0.042)\end{array}$ & $\begin{array}{c}0.0949^{*} \\
(0.034)\end{array}$ & & \\
\hline CONS & $\begin{array}{c}-0.0556 \\
(0.309) \\
\end{array}$ & $\begin{array}{c}-0.0532 \\
(0.322)\end{array}$ & $\begin{array}{c}0.0441^{* *} \\
(0.003)\end{array}$ & $\begin{array}{c}0.0485^{\star *} \\
(0.002)\end{array}$ \\
\hline $\begin{array}{l}\text { No. of obs.: } \\
\text { Adj. } R^{2} \text { : } \\
\text { AIC: } \\
\text { BIC: }\end{array}$ & $\begin{array}{c}12 \\
0.839 \\
-41.02 \\
-38.11\end{array}$ & $\begin{array}{c}12 \\
0.837 \\
-40.91 \\
-38.00\end{array}$ & $\begin{array}{c}12 \\
0.791 \\
-37,89 \\
-34.98\end{array}$ & $\begin{array}{c}12 \\
0.708 \\
-37.72 \\
-34.81\end{array}$ \\
\hline
\end{tabular}


The signs almost always coincide with their predicted value in all variables. Differences occur only in value of equity, where a positive relation appears. This relation, however, need not necessarily be incorrect, since there exist so called risk absorbing hypotheses such as (Allan \& Gale, 2004; Repullo, 2004) which present a positive relationship. Positive relations are more often detected in smaller banks or in banks which are not supported by the state to a great extent. Here, capital figures as an absorber of risk. In this case, this relation would fit well for Slovenian banks as well, since they are generally small. The positive relation of these two variables does not lead to pressure when increasing both capital regulation and regulation in the area of liquidity.
A different sign has also appeared in the case of the RATIO, where a positive relation could potentially signal the creation of liquidity reserves in case the excess of loans over deposits is increasing and the deposits themselves would not be sufficient for the realization of loans.

Other variables have shown the expected sign values - the creation of liquidity increases with the inflow of client deposits, and decreases with loans. However, if the realization of loans over deposits is higher than the bank chosen critical value, banks create liquidity. The quantities in Tab. 1 have a significant influence on the creation of liquidity, one of the liquidity flows. Tab. 2 presents the results for liquidity outflow (NEG), i.e. the other, reverse flow.

\section{Tab. 2: Results for outflow of liquidity (NEG)}

\begin{tabular}{|c|c|c|}
\hline NEG (outflow) & (1) & $(2)$ \\
\hline N_LOAN & $\begin{array}{l}1.261^{* *} \\
(0.001)\end{array}$ & \\
\hline G_LOAN & & $\begin{array}{l}1.054^{*} \\
(0.020)\end{array}$ \\
\hline TA & $\begin{array}{c}-1.926^{* *} \\
(0.001)\end{array}$ & $\begin{array}{c}-1.502^{*} \\
(0.019)\end{array}$ \\
\hline CONS & $\begin{array}{c}0.157^{\star * *} \\
(0.000)\end{array}$ & $\begin{array}{c}0.139^{\star \star *} \\
(0.000)\end{array}$ \\
\hline $\begin{array}{l}\text { No. of obs.: } \\
\text { Adj. } R^{2} \text { : } \\
\text { AIC: } \\
\text { BIC: }\end{array}$ & $\begin{array}{c}12 \\
0.217 \\
-24.06 \\
-22.61\end{array}$ & $\begin{array}{c}12 \\
0.067 \\
-21.96 \\
-20.51\end{array}$ \\
\hline
\end{tabular}

Source: author's calculation

Note: ${ }^{*} p<0.05,{ }^{* *} p<0.01,{ }^{* * *} p<0.001$

In the case of outflow, it seems that the main factors are the external ones. According to the determination coefficient, the model is explained in only $20 \%$. Important variables include loans and total size of the bank expressed by the total value of assets. The model was once again more conclusive when net loans were included instead of gross loans. The higher values of loans lead to an outflow of liquidity, which was implied by the predicted signs as well. The value of total assets suggests that if it is low, the outflow increases. It would thus seem that smaller banks are faced with a higher liquidity outflow than the large ones, which could be a reflection of the effects of the global crisis and the weakened position of smaller banks.

From the results presented so far, it is evident that for both flows, creation and outflow, the only common factor is the value of loans. This means that it is not possible to simply declare that if a factor affects one flow, it will have the opposite effect on the other. The results, show that a number of factors either do not figure at all or figure only insignificantly into liquidity outflow. It would be just as erroneous to assume that bank size, which had no effect on liquidity creation, does not affect liquidity (see, for example, Vodová, 2011a). The results for outflow show that an influence indeed exists. Tab. 3 presents the results for net flow (NET). 


\section{Finance}

\section{Tab. 3: Results for net changes (NET)}

\begin{tabular}{l|c|c|c}
\multicolumn{1}{c|}{ NET (net changes) } & $\mathbf{( 1 )}$ & $\mathbf{( 2 )}$ & $\mathbf{( 3 )}$ \\
\hline N_LOAN & $\begin{array}{c}-2.310^{* * *} \\
(0.001)\end{array}$ & $\begin{array}{c}-2.851^{* * *} \\
(0.000)\end{array}$ & \\
\hline G_LOAN & & & $-2.712^{\star * *}$ \\
& & & $(0.000)$ \\
\hline TA & $2.624^{* *}$ & $4.707^{* *}$ & $4.206^{* * *}$ \\
& $(0.008)$ & $(0.000)$ & $(0.000)$ \\
\hline T_DEP & $1.214^{* *}$ & & \\
& $(0.005)$ & & $0.285^{*}$ \\
\hline RATIO & & $0.232^{*}$ & $(0.034)$ \\
\hline CONS & & $(0.0340)$ & $-0.395^{*}$ \\
& $-0.0705^{*}$ & $-0.371^{*}$ & $(0.077)$ \\
\hline No. of obs.: & $(0.038)$ & $(0.030)$ & 12 \\
Adj. R2: & 12 & 12 & 0.447 \\
AIC: & 0.709 & 0.600 & -12.69 \\
BIC: & -20.40 & -16.58 & -10.75 \\
\hline & -18.46 & -14.64 &
\end{tabular}

Source: author's calculation

Note: ${ }^{*} p<0.05,{ }^{* *} p<0.01,{ }^{* * *} p<0.001$

\section{Tab. 4: Results for total reallocation (TOT)}

\begin{tabular}{l|c|c}
\multicolumn{1}{c|}{ TOT (reallocation) } & $(\mathbf{1})$ & $\mathbf{( 2 )}$ \\
\hline N_LOAN & $1.119^{* *}$ & \\
\hline G_LOAN & $(0.004)$ & $1.078^{* *}$ \\
& & $(0.007)$ \\
\hline TA & & $-1.344^{*}$ \\
& $-1.536^{*}$ & $(0.021)$ \\
\hline CONS & $(0.011)$ & $0.113^{* * *}$ \\
& $0.131^{* * *}$ & $(0.000)$ \\
\hline No of obs.: & $(0.000)$ & 12 \\
Adj. R2: & 12 & 0.202 \\
AIC: & $0 . .292$ & -29.66 \\
BIC: & -31.09 & -28.21 \\
\hline
\end{tabular}

Source: author's calculation

Note: ${ }^{*} p<0.05,{ }^{* *} p<0.01,{ }^{* * *} p<0.001$

Logically, the value of net (or gross) loans had a significant effect. It has been statistically significant for both flows, as increased value of loans causes an outflow of liquidity and a decrease in its creation (see Tab. 1 and 2), thus leading to a negative net change, and vice versa. In addition, the value of total assets has proven to be significant. Tab. 2 has shown that bank size has an effect mainly for liquidity outflow. It can thus be summarized that decreasing the value of total assets leads to a decrease of net change, which in this case is determined mainly by a higher liquidity outflow. The last variable which was shown to play 
a key role was the value of total deposits, with positive effect - that is, the growth in deposits leads to an increase in net change, mainly due to the creation of liquidity. For the positive relation between creation and client deposits, see Tab. 1. Finally comes the total activity in the system, i.e. reallocation (TOT). Tab. 4 presents the results.

A significant variable is the value of net (gross) loans as well as the value of total assets. It appears the influence of the factor on both flows as well as the maintaining of a certain loans/deposits ratio plays a role here. When loans grow, liquidity creation decreases and outflow increases. On the other hand, creation is renewed as long as loans and deposits maintain a certain ratio. Both flows thus take effect and reallocation increases. In the case of total assets, it seems that with the size of the bank, the activity decreases - the bank either creates liquidity, or uses it. Small banks, possibly also due to the proven increased outflow (see Tab. 2), are forced to create liquidity extensively to maintain at least a neutral position, and thus increase reallocation, i.e. activity.

\section{Conclusions}

It was the goal of this study to determine the internal factors of liquidity in the Slovenian banking sector using robust regression analyses. Aside from liquidity creation, which was often used by other studies, the dependent variables used included liquidity outflow, net changes and total reallocation, i.e. variables not used in other studies, to achieve greater complexity. The models have proven that the factors do not only affect liquidity creation, but affect other dimensions of liquidity as well. In addition, a given factor usually had a significant influence on one flow only, with loans and bank size alone having a simultaneous effect on multiple independent variables. Thus, when looking for determinants only for the creation or only for the outflow of liquidity, the results need not necessarily comprehensively show the influence of the given factors, and can lead to erroneous conclusions. This fact is evident for example in bank size which was not proven to have an influence on liquidity creation, but was a significant quantity in terms of liquidity outflow and total activity in the system. In this respect, the results suggested that smaller banks are faced with higher liquidity outflows and show higher activity. The results also show that banks also account for the risk in the loan portfolio, not only the portfolio's size, since the value of net loans showed a higher significance than the value of gross loans.

Even though the models were significant for other dimensions of liquidity as well, the biggest significance was achieved in liquidity creation. It thus seems that creation of liquidity is affected mainly by internal factors, while its outflow or total reallocation is more dependent on external factors instead.

The results of the models lead to the following conclusions: The creation of liquidity increases with growing client deposits, growing capital (here, it is important to mention that this positive influence does not lead to a trade-off between capital and liquidity, as the results of other studies have often shown, which would be evidence of a negative relation; see the literature review) and the growing value of the loans/deposits ratio. On the other hand, creation of liquidity decreases with growing profits and loans. Growing loans also lead to liquidity outflow. The outflow of liquidity, just like total activity in the system, is further affected by bank size.

This paper was created as a part of the project supported by an internal grant PEF (IGA PEF) Mendel University in Brno, PEF DP_2015_013 entitled: "Liquidity relationship with macroeconomic variables, variables on the level of banking sector and individual banks".

\section{References}

Allen, F., \& Gale, D. (2004). Financial Intermediaries and Markets. Econometrica, 72(4), 1023-1061. doi: 10.1111/j.14680262.2004.00525.x.

Bank for International Settlements. (2010). Basel III: International framework for liquidity risk measurement, standard and monitoring. Retrieved August 10, 2015, from http://www.bis. org/publ/bcbs188.pdf.

Berger, A. N., \& Bouwman, C. H. S. (2009). Financial Crises and Bank Liquidity Creation. Review of Financial Studies, 22(9), 3779-3837. doi:10.1093/rfs/hhn104.

Bonfim, D., \& Kim, M. (2012). Liquidity risk banking: Is there herding? [European Banking Center Discussion Paper 2012-024].

Bunda, I., \& Desquilbet, J. B. (2008). The bank liquidity smile across exchange rate 
regimes. International Economic Journal, 22(3), 361-386. doi:10.1080/10168730802287952.

Crockett, A. (2008). Market liquidity and financial stability. Financial Stability Review Special Issue on Liquidity, 11, 13-17.

Cucinelli, D. (2013). The Determinants of Bank Liquidity Risk within the Context of Euro Area. Interdisciplinary Journal of Research in Business, 2(10), 51-64.

Deep, A., \& Schaefer, G. (2004). Are Banks Liquidity Transformers? [Faculty Research Working Papers series, RWP04-022]. Harvard University.

Distinguin, I., Roulet, C., \& Tarazi, A. (2013). Bank regulatory capital and liquidity: Evidence from US and European publicly traded banks. Journal of Banking and Finance, 37(9), 3296-3317. doi:10.1016/j.jbankfin.2013.04.027.

Eroglu, N., \& Eroglu, I. (2011). The 2008 Global Financial Crisis and the Liquidity Management of the Central bank of the republic of Turkey. International Journal of Economics and Finance, 3(2), 186-193. doi:10.5539/ijef.v3n2p186.

Fungáčová, Z., Weill, L., \& Zhou, M. (2010). Bank Capital, Liquidity Creation and Deposit Insurance [BOFIT Discussion Papers, no. 17]. Bank of Finland.

Geršl, A., \& Komárková, Z. (2009). Liquidity Risk and Banks' Bidding Behavior: Evidence from the Global Financial Crisis. Czech Journal of Economics and Finance, 59(6), 577-592. doi:10.2139/ssrn.1703370.

Gorton, G., \& Winton, A. (2000). Liquidity Provision, Bank Capital, and the Macroeconomy. Retrieved August 9, 2015, from http://ejournal.narotama.ac.id/files/SSRNid253849.pdf.

Hackethal, A., Rauch, C., Steffen, S., \& Tyrell, M. (2010). Determinants of Bank Liquidity Creation. Social Science Research Network. doi:10.2139/ssrn.1343595.

Horvath, R., Seidler, J., \& Weill, L. (2012). Bank capital and liquidity creation. Granger-Causality evidence [Working paper series, no. 1947]. European Central Bank. doi:10.1007/s10693-013-0164-4.

Lakštutiene, A., \& Krušinskas, R. (2010). Lithuanian banks liquidity creation. Economics and Management (Ekonomika ir Vadyba), 2010(15), 986-991.

Laštůvková, J. (2014). Liquidity management strategies in the Czech banking sector [MENDELU Working Papers in Business and
Economics, 47/2014]. Mendel University in Brno.

Laštůvková, J. (2015). Determinants of the Slovak bank liquidity flows [MENDELU Working Papers in Business and Economics, 51/2015]. Mendel University in Brno.

Nguyen, M., Skully, M., \& Perera, S. (2013). The relationship between bank liquidity and stability: Does market power matter? Retrieved August 12, 2015, from http://www.financialrisksforum.com/risk2013/ work/6394870.pdf.

Moore, W. (2010). How do financial crises affect commercial bank liquidity? Evidence from Latin America and the Caribbean [MPRA Paper no. 21473].

Pana, E., Park, J., \& Query, T. (2010). The impact of bank mergers on liquidity creation. Journal of Risk Management in Financial Institutions, 4(1), 74-96.

Repullo, R. (2004). Capital Requirements, Market Power, and Risk-Taking in Banking. Journal of Financial Intermediation, 13(2), 156-182. doi:10.1016/j.jfi.2003.08.005.

Trenca, L., Petria, N., Mutu, S., \& Corovei, E. (2012). Evaluating the liquidity determinants in the central and eastern European banking system. Finance - Challenges of the Future, 12(14).

Valla, N., Saes-Escorbiac, B., \& Tiesset, M. (2006). Bank liquidity and financial stability. Financial Stability Review, 9, 89-104.

Vodová, P. (2011a). Liquidity of Czech Commercial Banks and its Determinants. International Journal of mathematical models and methods in applied sciences, 5(6), 1060-1067.

Vodová, P. (2011b). Determinants of commercial banks' liquidity in Slovakia. Lessons Learned from the Financial Crisis. In Proceedings of 13th International Conference on Finance and Banking.

Vodová, P. (2012). Determinants of commercial banks' liquidity in Poland. Proceedings of 30th International Conference Mathematical Methods in Economics (pp. 962967). Karviná: Silesian University, School of Business Administration.

Vodová, P. (2013). Determinants of commercial banks' liquidity in Hungary. Retrieved August 12, 2015, from http://www. slu.cz/opf/cz/informace/acta-academicakarviniensia/casopisy-aak/aak-rocnik-2013/ docs-1-2013/Vodova.pdf. 
Wagner, W. (2007). The liquidity of bank assets and banking stability. Journal of Banking \& Finance, 31(1), 121-139. doi:10.1016/j. jbankfin.2005.07.019.
Ing. Jana Laštůvková, Ph.D. Mendel University in Brno Faculty of Business and Economics Department of Finance Jana.lastuvkova@mendelu.cz 


\section{Abstract}

\section{DIMENSIONS OF LIQUIDITY AND THEIR FACTORS IN THE SLOVENIAN BANKING SECTOR}

\section{Jana Laštůvková}

The present article focuses on the internal factors which have potential influence on the liquidity of the Slovenian banking sector. Unlike other studies, this paper uses multiple dependent variables, encompassing different views on liquidity and leading to higher complexity. These include the creation of liquidity, its outflow, net change and total reallocation, determined on the basis of a specific method of liquidity measurement - the gross liquidity flows. The chosen independent variables include various items of internal character such as loans, deposits, profit, capital and the size of the bank. Robust regression analyses are performed. The results indicate that internal factors have the greatest influence on the creation of liquidity, where almost all the variables considered were significant. Used factors do not only affect liquidity creation, often investigated by authors, but affect other dimensions of liquidity as well. A significant item which played a role in multiple dimensions of liquidity was the value of loans and the size of the bank (total assets). The models have shown that any given factor only has an influence on the creation of liquidity without influencing its outflow and vice versa. Thus, when looking for determinants only for the creation or only for the outflow of liquidity, the results need not necessarily comprehensively show the influence of the given factors, and can lead to erroneous conclusions. It is therefore suitable to include multiple views on the value of liquidity, since the influence of a factor can be more dominant in a different dimension of liquidity and affect the final value. factors.

Key Words: Slovenian banking sector, dimension of liquidity, liquidity determinants, internal

JEL Classification: G21, G28.

DOI: 10.15240/tul/001/2017-2-012 